
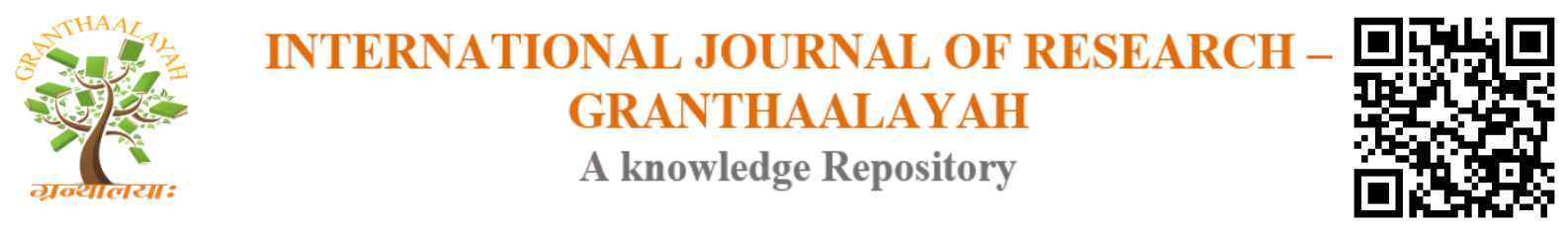

Science

\title{
PROSPECTS OF RAW MATERIALS FOR THE PRODUCTION OF BIODIESEL IN BRAZIL
}

\author{
Artur S. Rodrigues ${ }^{1}$, Adeline C. P. Rocha ${ }^{1}$, Alexandre Sylvio Vieira da Costa ${ }^{2}$, Izaldir A. \\ P. Lopes ${ }^{1}$
}

${ }^{1}$ Institute of Science and Technology, Federal University of Vales do Jequitinhonha and Mucuri

- UFVJM, Campus JK, Diamantina-MG, Brazil.

${ }^{2}$ Institute of Sciences, Engineering and Technologies, Federal University of Vales do Jequitinhonha and Mucuri UFVJM, Campus Mucuri, Teófilo Otoni -MG, Brazil

\begin{abstract}
Obtaining and offering bioenergy has been identified as promising alternatives to minimize the effects caused by the uncontrolled use of oil and its derivatives. Biofuels are examples of sources of bioenergy that seek to meet the social demand in the development and establishment of concepts in the generation of new industrial technologies. In this work, information was sought from different research sources, related to the historical context of the evolution of biodiesel production with emphasis on the perspectives of the raw materials that have been most researched today, such as macauba, microalgae, sewage sludge and residual oils. Such raw materials do not compete with food production; some have great environmental advantages, such as oil residue that stops being deposited in sewers to become an alternative fuel source. In order for these alternative resources to soy to be viable for the production of biodiesel on a large scale, it is increasingly necessary to encourage public and private sector policies to insert these biomasses into the biofuel market.
\end{abstract}

Keywords: Biodiversity; Biodiesel; Raw Materials; Vegetable Oils; Waste; Acrocomia Aculeata.

Cite This Article: Artur S. Rodrigues, Adeline C. P. Rocha, Alexandre Sylvio Vieira da Costa, and Izaldir A. P. Lopes. (2020). "PROSPECTS OF RAW MATERIALS FOR THE PRODUCTION OF BIODIESEL IN BRAZIL.” International Journal of Research - Granthaalayah, 8(4), 133143. https://doi.org/10.29121/granthaalayah.v8.i4.2020.18.

\section{Introduction}

Biofuels are promising sources of bioenergy that seek to meet the social demand in the development and establishment of concepts in the generation of new industrial technologies. Biodiesel is one of the main liquid biofuels studied, it is an alternative, promising and viable source for the replacement of petroleum diesel as it is biodegradable and derived from renewable sources (Faried et al., 2017). 
In Brazil, with the purpose of making biodiesel production and its use feasible, on January 13, 2005, the government implemented the National Biodiesel Production Program (PNPB), which established Law 11,097, which provides for the introduction of biodiesel in the Brazilian energy matrix. However, only in 2008, the addition of pure biodiesel (B100) to diesel oil became mandatory, starting with a 2\% (B2) percentage of addition, and currently, since September 2019, the required addition of 11\% (B11). The Resolution 16 of 29th October 2018 of the National Energy Policy Council (CNPE), which provides for the evolution of mandatory addition of biodiesel to diesel oil sold to final consumers in Brazil, establishes an increase of $1 \%$ per year in the minimum percentage mandatory addition of biodiesel by 2023, reaching the maximum percentage of $15 \%$ (B15) (ANP, 2019).

Recently, the Brazilian government created the National Biofuels Policy to fulfill the following objectives: to fulfill the commitments signed in the Paris Agreement (COP21), to promote the adequate expansion of biofuels in the energy matrix, to ensure predictability for the fuel market, to induce gains of energy efficiency, reduce greenhouse gas emissions in production, increase the commercialization and use of biofuels. This policy is publicly known as the RenovaBio Program, instituted by Law No. 13,576/2017. The program's goal, established by 2028, is decarbonisation by $10.1 \%$ reduction in the carbon intensity of the fuel matrix (ANP, 2019).

The main biodiesel production route is through a chemical process called transesterification. In this process, the triacylglyceride molecule is used, present in several raw materials from oils and fats of vegetable origin, oils and fats of animal origin or residual oils and fats. The molecule reacts with three alcohol molecules (methanol or ethanol), either in supercritical conditions or in the presence of catalysts (homogeneous, heterogeneous or enzymatic) producing three molecules of methyl or ethyl esters of fatty acid (biodiesel) and one molecule of glycerol (Cornejo et al ., 2017; Luo et al., 2016).

In addition to biodiversity, Brazil also has a large territorial extension, a very privileged geographical location with availability of water resources, plenty of light and good quality soils that originate the most varied plant species that can be used as raw material for the production of biodiesel. Plants like peanuts, corn, soybeans, palm oil, macauba, cotton, babassu, sunflower, castor, rapeseed, passion fruit, jatropha, avocado, octave, among many other vegetables in the form of seeds, almonds or pulps. Animal oils and fats have chemical structures very similar to those of vegetable oils, the main sources are beef tallow, fish oils, mocotó oil, lard, chicken fat, among others, these raw materials are usually from tanneries, slaughterhouses and animal slaughterhouses. Residual oils and fats from domestic, commercial and industrial processes are also used as raw material for the production of biodiesel. Recently, oils from algae and sewage sludge have also been investigated (BiodieselBR, 2019; ANP, 2019).

There are currently 51 industrial plants producing biodiesel authorized by the National Agency of Petroleum, Natural Gas and Biofuels (ANP) to operate in the country, corresponding to a total authorized capacity of 25,819.97 m3/day. However, the high cost of biodiesel induced by high raw material and process costs is the main obstacle that hinders its wide commercialization (Tabatabaei et al., 2019). In addition, there has been questioning the use of biodiesel derived from raw materials that require great demand for land for cultivation and that compete with the food industry. In this 
perspective, the objective of this work is to show the development of raw materials used in Brazil, aiming at improving the quality and quantity of biodiesel and carbon neutral economy.

\section{Materials and Methods}

This work is based in documentary exploratory research by collecting data from different sources, such as scientific articles and regulatory bodies of the activities within the industries of biofuels in Brazil, such as the National Agency of Petroleum, Natural Gas and Biofuels, created in 1997 by law No. 9,478.

Authors such as Mattar (1999) argue that exploratory research aims to provide the researcher with familiarity, knowledge and understanding on the research topic to be studied, using qualitative and quantitative methods in order to select and define concepts, state questions and hypotheses for future investigations. Written or unwritten sources, primary sources (documents) or secondary (books, magazines, and web) according to Marconi and Lakatos (2002), are the three fundamental variables for the documentary research process.

In this research work, information related are the subject of study have been sought, through searches on primary and secondary sources, in order to determine essential and relevant results of the studies analyzed. The bibliographic survey was researched in national and international scientific journals, research reports, books and official government publications focused on the area related to the biodiesel theme. In this sense, this work brings a brief analysis of the biodiesel scenario in Brazil, with a focus on the raw materials that have been most researched today, such as macauba, residual oils, sewage sludge and third and fourth generation microalgae (genetically modified), due to the fact that these biomasses do not compete with the food industry, which is one of the great challenges to mitigate the production of biodiesel, which today depends mainly on soy.

\section{Results and Discussions}

\subsection{Evolution of Biodiesel Production}

The first studies on biodiesel were developed by Rudolf Diesel and Henry Ford. In 1900, they showed at the Paris World's Fair the first engine powered by a biofuel derived from vegetable oil extracted from peanut oil. However, it was oil that was established as a raw material for the production of fuel used in engines, due to its high availability and low cost. (Suarez, and Meneghetti, 2007; Fernandes et al., 2015).

In the 1970s, the search by scientists and governments for viable alternatives to replace fossil fuels was rekindled, due to the oil crisis caused by the reduction in oil industry production that caused prices to rise. At the same time, there was a significant increase in research on alternative fuels. From the 1990s onwards, environmental issues arose, in addition to the existing economic and structural concerns, which linked the burning of fossil fuels with global warming. These factors further reinforced the need for sustainable alternatives to replace oil-derived fuels in the energy market. In this sense, several countries, including Brazil, started to develop research on the use of oils, fats and their derivatives as raw material for the production of liquid fuels (Lofrano, 2008). 
Biodiesel has emerged worldwide as a promising and viable alternative to fuels derived from oil. It has several important characteristics, such as being a renewable energy source and reducing the emission of polluting gases (Demirbas, 2007). Biodiesel is defined by the ANP as a biofuel derived from renewable biomass for use in internal combustion engines with compression ignition or, according to regulation, for another type of power generation that can partially or totally replace fossil fuels.

In Brazil, after several studies, the federal government launched the Brazilian Biodiesel Technological Development Program (Probiodiesel) in 2002, by Decree MCT No. 702, of October 30, 2002. The program has undergone changes and is called the Program National Production and Use of Biodiesel (PNPB), with biodiesel finally inserted in the Brazilian energy matrix by Federal Law No. 11,097 of January 13, 2005 (Pinho and Suarez, 2017). Since the introduction of diesel in the market, the mixture content with fossil diesel has evolved from $2 \%$ to currently $11 \%$, and together with the increase in the content, it is possible to observe the growth of biodiesel production in Figure. 1.

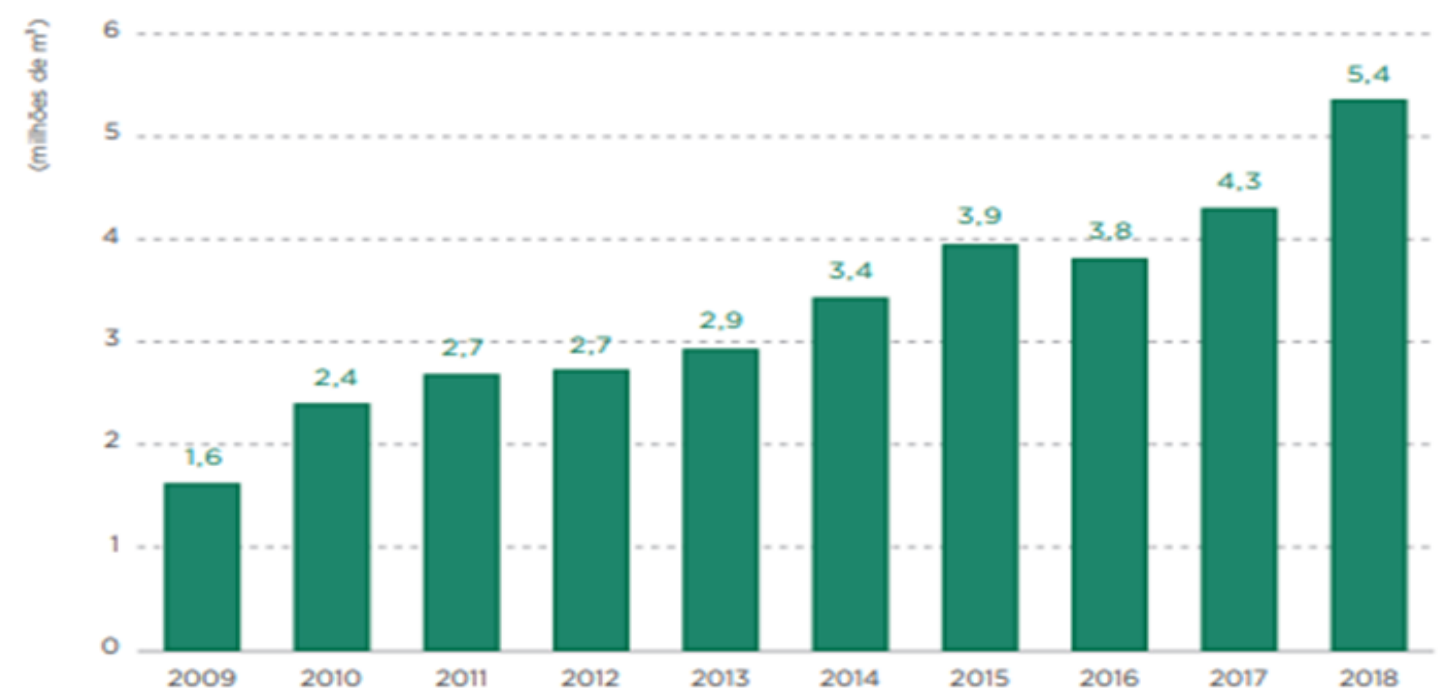

Figure 1: Evolution of Biodiesel production (B100) - 2009 to 2018.

Source: ANP/SPC (YEAR).

The fuels derived from renewable raw materials are gaining space in the Brazilian market. The proposal for a gradual increase is to reach the addition of $15 \%$ (B15) of the mandatory percentage of biodiesel to diesel oil by 2023, and this growth represents an $85 \%$ increase in demand. With this, Brazil should consolidate as one of the largest producers worldwide biodiesel, since the since the production estimate is expected to increase from 5.4 to more than 10 billion liters annually $\mathrm{s}$ (Ministry of Mines and Energy, 2019).

\subsection{Production Brazilian Biodiesel by Region}

In 2018, the nominal production capacity of biodiesel (B100) in Brazil, was 8.5 million m3, equivalent to 23.6 thousand $\mathrm{m} 3 /$ day. However, national production was 5.4 million $\mathrm{m} 3$, which corresponded to $63.5 \%$ of the total capacity. Compared to 2017 , biodiesel production was $24.7 \%$ higher. The Northeast region had an exponential highlight of $1,195.7 \%$ in the production of the 
period this is due to the manufacture of the State of Tocantins, which had an increase of $15,066.8 \%$ in the generation of Biodiesel. There was also an increase in the Southeast, Northeast, South and Midwest regions, of 37\%, 29.4\%, 24.8\% and $16.8 \%$, respectively. However, the largest producer of biodiesel in Brazil is the Midwest Region, with a volume of around 2.22 million m3, equivalent to $41.4 \%$ of national production. Then came the South Region, with a production of 2.20 million $\mathrm{m} 3,41.1 \%$ of the national total. The production in the South Region is almost equal to that in the Midwest Region, due to the state of Rio Grande do Sul, which continues to be the largest producer of biodiesel, with a volume of approximately 1.5 million $\mathrm{m} 3$, equivalent $27.7 \%$ of the national total. Being larger than the North, Southeast and Northeast Regions, which together have only 17.5\%. Next came the State of Mato Grosso, with 1.13 million $\mathrm{m} 3$ (21.2\% of the national total), with a $24 \%$ increase in production as can be seen in Table 1.

Table 1: Biodiesel production (B100), by Major Region and Federation Unit - 2009-2018.

\begin{tabular}{|c|c|c|c|c|c|c|c|c|c|c|c|}
\hline \multirow{2}{*}{$\begin{array}{l}\text { Major Regions and } \\
\text { Federation Units }\end{array}$} & \multicolumn{10}{|c|}{ Biodiesel production $(\mathrm{B} 100)-\left(\mathrm{m}^{3}\right)$} & \multirow{2}{*}{$\begin{array}{c}18 / 17 \\
\%\end{array}$} \\
\hline & 2009 & 2010 & 2011 & 2012 & 2013 & 2014 & 2015 & 2016 & 2017 & 2018 & \\
\hline Brazil & 1.608.448 & 2.386 .399 & 2.672 .760 & 2.717 .483 & 2.917.488 & 3.419.838 & 3.937.269 & 3.801.339 & 4.291.294 & 5.350 .036 & 24,67 \\
\hline North Region & 41.821 & 95.106 & 103.446 & 78.654 & 62.239 & 84.581 & 66.225 & 38.958 & 7.821 & 101.339 & $1.195,68$ \\
\hline Rondônia & 4.779 & 6.190 & 2.264 & 8.406 & 13.553 & 10.977 & 4.140 & 1.035 & 7.260 & 16.232 & 123,57 \\
\hline Pará & 3.494 & 2.345 & - & - & - & - & - & - & - & - & . \\
\hline Tocantins & 33.547 & 86.570 & 101.182 & 70.247 & 48.687 & 73.604 & 62.085 & 37.923 & 561 & 85.107 & $15.066,83$ \\
\hline Northeast Region & 163.905 & 176.994 & $\mathbf{1 7 6 . 4 1 7}$ & 293.573 & 278.379 & 233.176 & 314.717 & 304.605 & 290.945 & 376.338 & 29,35 \\
\hline Maranhão & 31.195 & 18.705 & - & - & - & - & - & - & - & - & .. \\
\hline Piauí & 3.616 & - & - & - & - & - & - & - & - & - & .. \\
\hline Ceará & 49.154 & 66.337 & 44.524 & 62.369 & 84.191 & 72.984 & 87.434 & 59.390 & - & - & .. \\
\hline Rio Gra & - & - & - & - & - & - & 1.799 & - & - & - & .. \\
\hline Bahia & 79.941 & 91.952 & 131.893 & 231.204 & 194.188 & 160.192 & 225.484 & 245.215 & 290.945 & 376.338 & 29,35 \\
\hline Southeast Pegion & 284.774 & 420.328 & 379.410 & 255.733 & 261.373 & 270.891 & 295.436 & 254.259 & 334.058 & 457.702 & 37,01 \\
\hline Minas Gerais & 40.271 & 72.693 & 76.619 & 80.100 & 88.020 & 83.283 & 92.258 & 94.798 & 118.136 & 127.946 & 8,30 \\
\hline Rio de Janeiro & 8.201 & 20.177 & 7.716 & 17.046 & 8.891 & 17.262 & 18.704 & 21.669 & 58.237 & 96.103 & 65,02 \\
\hline São Paulo & 236.302 & 327.458 & 295.076 & 158.587 & 164.462 & 170.345 & 184.473 & 137.791 & 157.685 & 233.653 & 48,18 \\
\hline South region & 477.871 & 675.668 & 976.928 & 926.611 & 1.132 .405 & 1.358 .949 & 1.512 .484 & 1.556 .690 & 1.762 .185 & 2.198 .946 & 24,79 \\
\hline Paraná & 23.681 & 69.670 & 114.819 & 120.111 & 210.716 & 319.222 & 363.689 & 392.679 & 504.244 & 597.348 & 18,46 \\
\hline Santa Catarina & - & - & - & - & 38.358 & 68.452 & 34.489 & 89.252 & 121.965 & 122.131 & 0,14 \\
\hline Rio Grande do Sul & 454.189 & 605.998 & 862.110 & 806.500 & 883.331 & 971.275 & 1.114 .307 & 1.074 .759 & 1.135 .976 & 1.479 .467 & 30,24 \\
\hline Midwest Region & 640.077 & 1.018.303 & 1.036 .559 & 1.162 .913 & \begin{tabular}{|l|l|}
1.183 .092 \\
\end{tabular} & 1.472 .242 & 1.748.407 & 1.646 .828 & 1.896 .284 & 2.215 .712 & 16,84 \\
\hline Mato Grosso do Sul & 4.367 & 7.828 & 31.023 & 84.054 & 188.897 & 217.297 & 207.484 & 178.237 & 265.707 & 324.483 & 22,12 \\
\hline Mato Grosso & 367.009 & 568.181 & 499.950 & 477.713 & 418.480 & 611.108 & 845.671 & 818.669 & 914.007 & 1.133 .560 & 24,02 \\
\hline Goiás & 268.702 & 442.293 & 505.586 & 601.146 & 575.715 & 643.837 & 695.252 & 649.922 & 716.570 & 757.669 & 5,74 \\
\hline
\end{tabular}

Source: ANP (2019).

\subsection{Raw Materials for Biodiesel Production in Brazil}

Biodiesel in general is gaining worldwide attention as an alternative fuel option, with the aim of replacing the use of diesel derived from conventional fossil sources. Nowadays, a wide research is being carried out all over the world for the production of fuels from renewable biomass, replacing the traditional sources currently used fossils, in addition to being an exhaustible source it provides irreversible environmental damage.

These new sources of energy are liquid vegetable oils, animal fats and residues. Liquid vegetable oils extracted from soybean, cotton, peanuts, canola, palm, sunflower and castor. Animal fats are mostly solid depending on the temperature (beef tallow, fish oil and pork fat). Residues can be raw 
materials related to the urban environment, such as waste oils from domestic and industrial kitchens and the sewage itself (Câmara, 2006).

In 2018, the main raw material for biodiesel generation (B100) in Brazil was soy, which was equivalent to $58.74 \%$ of its total production (ANP, 2018). Compared to the previous year, 2017 , soybean production was equivalent to $71.6 \%$ of the total. This percentage decrease in soy use can be attributed to the emergence of new raw materials such as: palm oil, peanut oil, turnip oil, sunflower oil, castor oil, sesame oil, canola oil, corn, used frying oil and other fatty materials used in the production of biodiesel, since these had a highlight of $42.9 \%$, while soybeans, obtained only $22.5 \%$. The second feedstock in the production ranking the plants was the animal fat $(16.2 \%$ of total) after lifting $19.3 \%$ compared to 2017 , followed by other fatty materials (42.9\% of total) and cotton oil $295.7 \%$ stake (Figure 2 ).

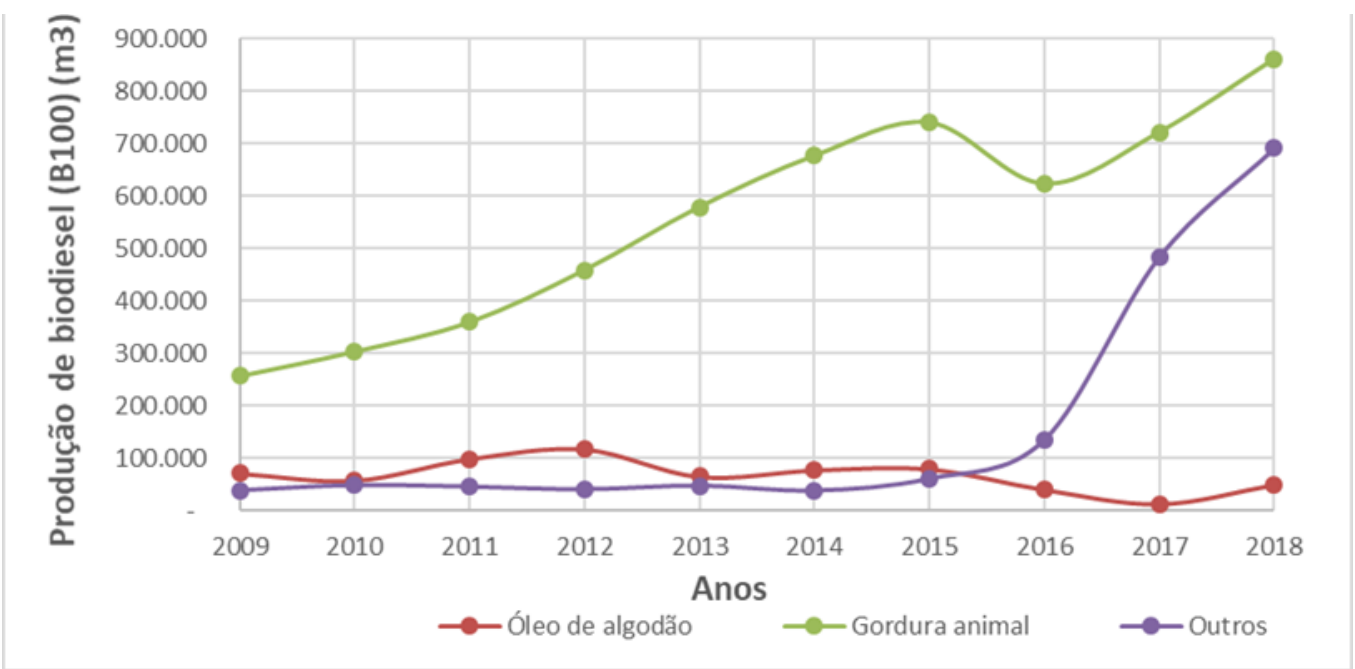

Figure 2: Raw materials used in the production of biodiesel (B100).

Source: ANP (2019).

The following topics describe some raw materials, alternatives for the production of biodiesel in Brazil, with an emphasis on those that are the most researched and that do not compete with the food industry.

\subsubsection{Macauba}

Acrocomia aculeata, known as macaúba in central Brazil, also known as macaíba in the Northeast; or, still, bocaiúva in the states of Mato Grosso and Mato Grosso do Sul, it is a rustic plant, with perennial and prickly leaves, with trunks of 20 to $30 \mathrm{~cm}$ in diameter and can reach 20 meters in height. Macauba begins to bear fruit around 5 years after planting, and can produce them for approximately 100 years (Embrapa, 2014).

According to Brazilian Agricultural Research Corporation (Embrapa), this fruit is found in almost all Brazilian territory, and is more frequent in Minas Gerais, São Paulo, Goiás, Mato Grosso do Sul, Mato Grosso, Tocantins, Piauí and Ceará, in an isolated way or forming natural stands called "massive". It is a palm with great potential for use, as food, as cosmetics and as energy purposes, 
leaving virtually no usable residues. Its fruits or coconuts are the most economically important part of the plant, and can also be consumed as food.

The occurrence of large native populations of macauba with high oil content, in the Southeast and central Brazil, especially in the state of Minas Gerais, has been one of the determining factors for the exploration of its oil in the country. Such extractive activities contributed significantly to demonstrate the feasibility of using palm trees for oil production and energy cogeneration in Brazil, with environmental, economic and social advantages (Navarro et al, 2014).

This fruit has an interesting productivity that places it among the main agroenergy crops: $25 \mathrm{t}$ of fruit.ha- 1.year - 1 with a high oil content (50-75\%), that is, $6,200 \mathrm{~kg}$ of oil.ha- 1.year - 1 , comparable to the production obtained from the African oil palm (Elaeis guineensis Jacq.) (Cesar et al., 2015). The high yield potential, diversity of co-products and several positive characteristics of this emerging energy culture make it an interesting option from the social and environmental point of view for the production of biodiesel throughout the national territory.

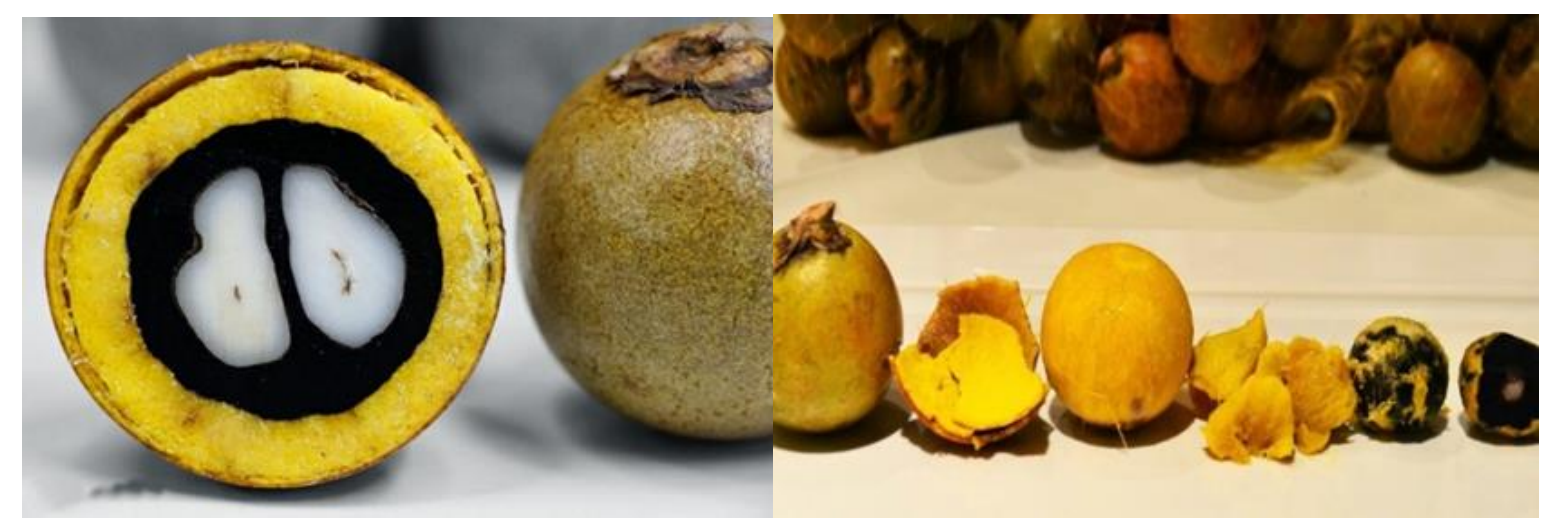

Figure 3: Macaw fruit and its parts

Source: Google Images (2020).

\subsubsection{Residual Oils}

For the production of biodiesel, residual oils and fats originated domestic, commercial and industrial use can also be recycled as raw material. This type of oil can be found easily in several places such as: restaurants, fast food chains, in municipal sewers, snack bars, in addition to industrial kitchens where food is fried in greater quantities (Garcilasso, 2014).

A procedure widely used in food production is deep-frying, which uses vegetable fat oils as a means of transferring heat. This procedure is harmful to the environment, as it generates a significant volume of oils and fats that do not have an adequate disposal, considering that more than $80 \%$ is consumed in homes. With this, the oil poured into the sewage system pollutes the water and, consequently, the rivers, aquifers and the soil (Araujo, 2013).

The time of use of these oils, which can vary for each establishment, also becomes a problem, because, in the long term, an oxidation process occurs, which is accelerated by high temperature and ends up generating by-products that alter the physical and chemical properties of the oil, making it unsuitable for use. 
Technically, it was found that used cooking oil biodiesel has properties similar to those of vegetable oil raw materials biodiesel, when emissions and exhaust performance tests were carried out (Knothe, 2019). Therefore, the same advantages attributed to "classic" biodiesel can also be applied to biodiesel derived from this raw material, such as renewability, biodegradability and lubrication. However, the disadvantages are also similar, although the residual oil present an even higher viscosity level due to the fact that it also has a higher content of free fatty acids, it was an abundant resource with no use until the present, being discarded in rivers, lakes, sewers polluting them and causing damage to human, animal and plant health.

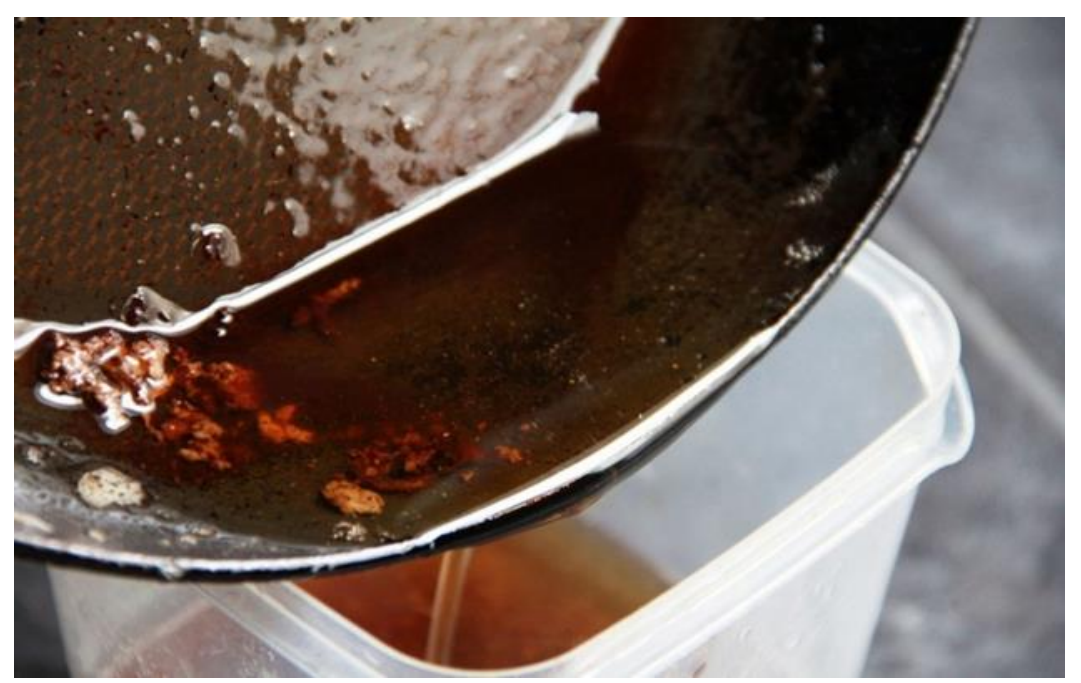

Figure 4: Process for separating residual frying oil.

Source: Google Images (2020).

\subsubsection{Sewage Sludge}

Sewage management is a worldwide problem. Due to the increase in population and rapid industrialization, there is an increase in the number of sewage sludge collected from the wastewater treatment plant (WWTP). As a result, the amount of sewage sludge produced from WWTPs has increased dramatically in recent decades, thus causing a harmful effect on the environment and on humans.

The main obstacle that stands in the way of commercialization of the biodiesel industry is the cost of its raw material (mainly vegetable oils), responsible for more than $80 \%$ of the production cost. Researchers are analyzing different sources of non-edible oil, such as algae, jatropha, macauba, among others, as suitable alternatives for the biodiesel raw material, but this requires huge land for cultivation and its ease of availability is a matter of concern (Revellame, 2011). Therefore, it is extremely important to look for an alternative raw material for biodiesel that is readily available and cheap.

As a result, municipal sewage sludge (MSS) is gaining worldwide attention, as it is an abundant organic waste and contains a significant amount of lipids, which can make the production of biodiesel from sewage sludge profitable. In addition, it can also be considered as a potential source of food for the production of biodiesel due to its low cost and abundant availability (JARDÉ, 2005). 


\subsubsection{Microalgae}

The intense use of natural fuel resources is threatening the global environment and the sustainability of society. This triggers the need to find sustainable and environmentally friendly energy sources. In this perspective, microalgae have emerged as a potential alternative. Microalgae are characterized with a distinct ability to provide ecological services and respond to sustainability challenges simultaneously. Microalgae can fix atmospheric $\mathrm{CO} 2$, valorize wasted resources and can produce a wide variety of bio-products (Javed, 2019).

Microalgae is one of the most executable biomasses for industrialization without harmful effects to the environment. They can grow in fresh, residual or seawater. The cultivation of algae does not require fresh water, agricultural land and, however, it has a high biomass yield with high oil content. Techniques that employ microalgae, such as anaerobic digestion in methane, microalgae oil in biodiesel and photobiological conversion into hydrogen, can produce various renewable biofuels. Biofuel production is not a new concept. However, microalgae are impeded by many commercialization challenges, such as energy deficiency and high cost processes for growing and harvesting algae with significant amounts of necessary nutrients, such as nitrogen (N) and phosphorus (P), with conventional farming methods (Elrayies, 2018). Therefore, we have to look for ways to improve and new technologies to supply and reduce the costs of biodiesel production through this very renewable and new resource.

Table 2 below, compare productivity and photosynthetic efficiency of various types of biofuels. We can see that the discrepancy in the production of biodiesel through microalgae is very relevant in relation to other products.

Table 2: Comparison of the productivity and photosynthetic efficiency of various types of biofuels.

\begin{tabular}{|l|c|c|c|}
\hline Biomass Sources & Type of fuel produced & $\begin{array}{c}\text { Productivity } \\
\text { (ha }^{-\mathbf{1}} \text { year }^{-\mathbf{1}} \text { ) }\end{array}$ & Photosynthetic efficiency \\
\hline Corn & Ethanol & 20 & 0.2 \\
\hline Sugar cane & Ethane & $210-250$ & 2 to 3 \\
\hline Soy & Biodiesel & $13-22$ & 0.1 to 0.2 \\
\hline Sunflower & Biodiesel & $8.7-16$ & 0.1 to 0.2 \\
\hline Microalgae & Biodiesel & $390-700$ & 4 to 7 \\
\hline
\end{tabular}

Source: FRANCO (2013).

\section{Conclusions and Recommendations}

The main raw material used for the production of biodiesel in Brazil is soybeans, due to its largescale cultivation, which makes this oilseed the only one with sufficient production capacity to meet the demand immediately for oil for energy purposes, in addition to its great market turning capacity. However, as the future prospects point to the growth of biodiesel production, to meet the demand it will be necessary to expand the planted area for energy purposes, thus raising concerns such as the reduction of planted areas, excessive water consumption and reduced supply of agricultural inputs, like fertilizers. In addition, currently one of the main discussions about biodiesel from soy biomass raises about the close relationship between energy and food. 
Over time, food and energy have competed for economic/natural resources around the world. In this sense, the search for raw materials that do not compromise food security is essential to make the biodiesel production chain viable. Biomass from residues is an alternative that has shown itself to be very promising, in addition to not competing with food production, they have great environmental advantages, because when oil residue stops being deposited in sewers to become an alternative source of fuel. Finally, in order for alternative resources to soy, such as macauba, residual frying oil, sewage sludge and microalgae to be viable for large-scale biodiesel production, it is increasingly necessary to encourage public and private sector policies to insert these biomasses into the biofuels market.

\section{Acknowledgements}

The Coordination for the Improvement of Higher Education Personnel (CAPES) and the Minas Gerais State Research Support Foundation (FAPEMIG).

\section{References}

[1] ANP- National Agency for Petroleum, Natural Gas and Biofuels. 2019. Available on: http://www.anp.gov.br/wwwanp/.

[2] Brazilian statistical yearbook of oil, natural gas and biofuels:. The National Agency of Petroleum, Natural Gas and Biofuels. - Rio de Janeiro: ANP, 2018.

[3] Biodiesel, BR Biodiesel production. 2019. Available on: https://www.biodieselbr.com/noticias/materia-prima.

[4] Camara, G.M.S. Biodiesel Brasil-current state of the art. Oilseed Agribusiness: Raw Materials for Biodiesel. Piracicaba: ESALQ, 2006, 123-153.

[5] Cornejo, A., Barrio, I., Campoy, M., Lazaro, J., Navarrete, B. Oxygenated fuel additives from glycerol valorization. Main production pathways and effects on fuel properties and engine performance: A critical review, Renewable and Sustainable Energy Reviews 79, 2017,1400-1413.

[6] Cesar, A.S., Almeida, F.A., Souza, R.P., Silva, G.C., Atabani, A. E.The prospects of using Acrocomia aculeata (macaúba) a non- edible biodiesel feedstock in Brazil. Renewable and Sustainable Energy Reviews, 49, 2015,1213-1220.

[7] Araujo, Mandolesi, C.D. Biodiesel production from used cooking oil: a review. Revisions on renewable and sustainable energy, 27, 2013,445-452.

[8] Demirbas, A. 2007.Progress and recent trends in biofuels. Progress in energy and combustion science, 33(1), 2007,1-18.

[9] Embrapa. Brazilian Agricultural Research Corporation. 2019. Available on: https://www.embrapa.br/busca-de-noticias/-/noticia/2329636/macauba-e-materia-primapromissora-para-biodiesel.

[10] Elrayies,G.M.Microalgae: prospects for greener future buildings. Renewable and Sustainable Energy Reviews, 81, 2018,1175-1191.

[11] Faried, M., Samer, M., Abdelsalam, E., Yousef, R.S., Attia, Y.A.; Ali, A.S. Biodiesel production from microalgae: Processes, technologies and recent advancements. Renewable and Sustainable Energy Reviews, 79, 2017, 893-913.

[12] Fernandes, F.M., Silva, M.S., Lima, A., Rocha, A.M., Soares, P.M., Konish, F. Biodiesel in the world and in Brazil: current situation and future scenarios. In: Congress on distributed generation and energy in rural areas. 2015

[13] Franco, A. L. C., Lobo, I.P., Cruz, R. S. D., Teixeira, C. M. L. L., Neto, J.A. D., Menezes, R.S. Biodiesel from microalgae: progress and challenges. Química Nova, 36(3), 2013, 437-448. 
[14] Garcilasso, V. P. Analysis between processes and raw materials for the production of biodiesel. Doctoral thesis. University of Sao Paulo, 2014.

[15] Jarde, E., Mansuy, L., Faure, P. Organic markers in the lipidic fraction of sewage sludges. Water research, 39 (7), 2005,1215-1232.

[16] Javed, F., Aslam, M., Rashid, N., Shamair, Z., Khan, A. L., Yasin, M., Khan, Z. Microalgae-based biofuels, resource recovery and wastewater treatment: A pathway towards sustainable biorefinery. Fuel, 255, 2019,115826.

[17] Knothe, G., Steidley, K. R. A comparison of used cooking oils: a very heterogeneous raw material for biodiesel. Biorresource technology, 100(23), 2009, 5796-5801.

[18] Lofrano, R. C. Z. A review of biodiesel. Scientific Journal of UNIFAE,2, 2008, 2-5.

[19] Luo, X., Ge, X., Cui, S., Li, Y.Value added processing of crude glycerol into chemicals and polymers. Bioresource Technology, 215, 2016,144-154.

[20] Marconi, M. A., Lakatos, E. M. Research techniques: planning and execution of research, sampling and research techniques, elaboration, analysis and interpretation of data. São Paulo, Atlas. 2002.

[21] Mattar, F.N.Marketing research: methodology, planning. São Paulo, Atlas, 1999.

[22] MME. Ministry of Mines and Energy. 2019. Available on: http://www.mme.gov.br/web/guest/pagina-inicial/outras-noticas//asset_publisher/32hLrOzMKwWb/content/biocombustiveis-producao-e-consumo-seguem-emalta-no-pais.

[23] Navarro-dias, H. J., Gonzalez, S. L., Irigaray, B., Vieitez, I., Jachmanian, I., Hense, H., Oliveira, J. V. Macauba oil as an alternative feedstock for biodiesel: characterization and ester conversion by the supercritical method. The Journal of Supercritical Fluids, 9, 2014,130-137.

[24] Pinho, D. M. M., Suarez, P.A. Z. From peanut oil to biodiesel-Historic and Brazilian policy for the energy use of oils and fats. Virtual Journal of Chemistry, 9(1), 2017, 39-51.

[25] Revellame, E., Hernandez, R., French, W., Holmes, W., Alley, E., Callahan I. I. R. Production of biodiesel from wet activated sludge. Journal of Chemical Technology \& Biotechnology, 86(1), 2011, 61-68.

[26] Singh, D., Sharma, D., Soni, S. L., Sharma, S., Sharma, P. K., Jhalani, A. A review on feedstocks, production processes, and yield for different generations of biodiesel. Fuel. 262, 2019,116553.

[27] Suarez, P. A. Z., Meneghetti, S. M. P. 70th anniversary of biodiesel in 2007: historical evolution and current situation in Brazil. New Chemistry, 30(8), 2007, 2068-2071.

[28] Tabatabaei, M. Aghbashlo, M. Dehhaghi, M. Panahi, H. K. S., Mollahosseini, A. Hosseini, M., Soufiyan, M.Reactor technologies for biodiesel production and processing: A review. Progress in Energy and Combustion Science, 7, 2019, 239-303.

* Corresponding author.

E-mail address: al exandre.costa@ufvjm.edu.br 